Research article

\title{
SERUM PROTEINS AND LIPIDS IN MILD FORM OF CALF BRONCHOPNEUMONIA: CANDIDATES FOR RELIABLE BIOMARKERS
}

\author{
KOVAČIĆ Marijana ${ }^{1}$, MARKOVIĆ Dragana ${ }^{1}$, MASLOVARIĆ Irina ${ }^{1}$, OBRENOVIĆ \\ Sonja ${ }^{2}$, GRUJIĆ-MILANOVIĆ Jelica ${ }^{1}$, ARSIĆ Aleksandra ${ }^{1}$, MILANOVIĆ Zorana ${ }^{3}$, \\ SAVIĆ Olivera ${ }^{4}$, FRATRIĆ Natalija ${ }^{5, a}$, ILIĆ Vesna ${ }^{1, a, *}$
}

${ }^{1}$ Institute for Medical Research, University of Belgrade, Dr Subotića 4, Belgrade, Serbia; ${ }^{2}$ Department of Infectious Animals Diseases and Diseases of Bees, Faculty of Veterinary Medicine, University of Belgrade, Bulevar oslobodjenja 18, Belgrade, Serbia; ${ }^{3}$ Department of Pathophysiology, Faculty of Veterinary Medicine, University of Belgrade, Bulevar oslobodjenja 18, Belgrade, Serbia; ${ }^{4}$ Institute for Blood Transfusion of Serbia, Svetog Save 39, Belgrade, Serbia; ${ }^{5}$ Department of Physiology and Biochemistry, Faculty of Veterinary Medicine, University of Belgrade, Bulevar oslobodjenja 18, Belgrade, Serbia

(Received 09 November, Accepted 26 December 2016)

Calf bronchopneumonia is complex multifactorial disease and for its accurate diagnosis and therapy, besides clinical examination, microbiologic, hematologic and biochemical analyses could be necessary. In general, additional analyses are not implemented, mainly because the disease biomarkers are not defined.

To establish which analysis might be useful for determining the severity of the disease, we analyzed 23 three-month old calves with mild clinical signs of bronchopneumonia and 15 age-matched healthy calves. Pasteurella multocida was isolated from deep nasal swabs of diseased calves. Peripheral blood erythrocyte and leukocyte count of bronchopneumonic and healthy calves showed no difference. Serum proteins, lipoproteins and lipids were analyzed with spectrophotometry, agarose gel electrophoresis, non-reducing SDSPAGE, gel zymography, and thin-layer chromatography. The bronchopneumonic calves had an increased level of circulating immune complexes and $\alpha$ globulins, which contain some of the positive acute phase proteins. In diseased calves the increased concentration of total $\gamma$ globulins ( $\operatorname{IgG}$ ), due to an increased concentration of anionic $\gamma$ globulins (predominately $\operatorname{IgG} 1$ ), was detected. The increased concentration of anionic $\gamma$ globulins followed by increased concentration of transferrin (negative acute phase protein) and HDL cholesterol, decreased concentration of LDL-cholesterol, unchanged activity of matrix metalloproteases and leukocyte counts might reflect the obvious absence of generalized inflammation. A positive correlation was found between the acquired results and the appearance of mild clinical signs. Therefore, we believe that the parameters analyzed in the peripheral blood could be applied as reliable

\footnotetext{
*Corresponding author: e-mail: vesnai@imi.bg.ac.rs

ajoint principal investigators
} 
disease markers to distinguish between severe (inflammatory) and mild forms of calf bronchopneumonia and to predict a better outcome for these calves.

Key words: biomarkers, calf bronchopneumonia, serum lipids, serum proteins

\section{INTRODUCTION}

Respiratory diseases are considered the second most important cause of death in calves and a leading cause of economic loss in the cattle industry worldwide. The diseases have huge negative economic impact associated with death loss and treatment costs, reduction of live weight gain and reduced productive life span. Calf bronchopneumonia is a complex disease caused by viruses (BHV-1, PI-3V, BVDV, BRSV) or/and bacteria (Mannheimia haemolytica, Pasteurella multocida, Haemophilus somnus, Mycoplasma spp.). These infectious agents are ubiquitous in cattle populations, and the disease occurs when the calf's immune defense is diminished by environmental stress factors (weaning, transport, crowding, unfavorable weather condition, dust, poor ventilation, malnutrition, etc.) [1].

Even nowadays the diagnosis of calf bronchopneumonia is based mostly on clinical observation. Isolation of causative microbiological agents and hematological, biochemical, and immunological analyses have been widely applied in epidemiological surveys and basic and applied research of the disease pathogenesis [2-11]. Most of these methods are available for veterinary practice; however, they are extremely rarely, if at all, used for the diagnosis of calf bronchopneumonia. We assume that the main reason for such non-implementation of modern diagnostic methods is the absence of well-defined biomarkers of the disease. Although acute phase proteins (haptoglobin, serum amyloid A, alpha(1)-acid glycoprotein, fibrinogen) have been considered to be reliable biomarkers of the diseases [5-7,12,13] a recent meta-analysis has cast doubt on it [14]. Further acute phase proteins, peripheral blood leukocyte count, hemoglobin concentration, blood $\mathrm{CO}_{2}$ and $\mathrm{O}_{2}$, circulating immune complexes, serum protein fractions, alanine aminotransferase (AST), aspartate aminotransferase (ALT), alkaline phosphatase (ALP), and low-density lipoprotein (LDL) cholesterol have also been considered as reliable disease markers $[8,11-13,15-18]$ but the results are not always consistent.

We believe that this inconsistency is a consequence of the complex etiology of calf bronchopneumonia, which results in a broad spectrum of disease forms ranging from mild to severe and lethal. As it was noted, diagnosis based only on clinical observation is not fully adequate for calves with mild clinical symptoms, which might therefore remain undiagnosed. With the aim to more precisely define a reliable set of indictors of pneumonia in calves with mild clinical symptoms we analyzed their circulating immune complexes, serum proteins, lipoproteins and lipids with widely available, inexpensive, and non labor-intensive methods, which can be applicable for livestock farming and can also provide significant data on the pathogenesis of calf bronchopneumonia. 


\section{MATERIAL AND METHODS}

\section{Calves}

Holstein-Friesian calves $(n=38)$ were from a farm owned by PKB Corporation (Padinska Skela, Belgrade, Serbia). The use of animals was approved by the Ethical Committee of the Faculty of Veterinary Medicine, University of Belgrade in accordance with the National Regulation on Animal Welfare. All calves were clinically examined by a veterinarian. The calves were classified according to signs of respiratory disease as healthy $(n=15)$ or diseased $(n=23)$. Healthy animals had body temperature $<39.5^{\circ} \mathrm{C}$, respiratory rate $<40 \mathrm{~min}^{-1}$, no nasal discharge, no coughing and normal respiratory sounds. Diseased animals had at least three of the following clinical signs: body temperature $\geq 39.5{ }^{\circ} \mathrm{C}$, respiratory rate $\geq 45 \mathrm{~min}^{-1}$, nasal discharge, coughing or increased respiratory sounds. The overall clinical score was calculated according to McGuirk [19]. The recorded clinical symptoms were mild.

In order to identify the bacteria and ensure adequate antibiotic therapy, deep nasal swabs were taken. Tests were done by applying conventional bacteriological methods and an automatic identification system, BBL Crystal 134 Enteric/nonfermenter ID kit (Becton Dickinson GmbH, Heidelberg, Germany), at the Department of Microbiology and Immunology, Faculty of Veterinary Medicine, Belgrade. All samples from diseased calves were positive for Pasteurella multocida, while other pathogenic bacteria and fungi were not isolated. In nasal swab specimens of healthy calves no pathogenic bacteria or fungi were isolated. The analysis of basic hematological parameters of peripheral blood of these calves was done at the Faculty of Veterinary Medicine, Belgrade using the Hematology Analyzer 901062 (Diatron, Arcus, GmbH, Wien, Austria). Blood for hematological analysis was collected into plastic tubes with $\mathrm{K}_{2}$ EDTA as anticoagulant (BD Vacutainer ${ }^{\circledR}$ Venous Blood Collection, BD Diagnostics, NJ, USA).

\section{Blood serum}

Blood samples from diseased calves, prior to treatment with antibiotics, and healthy calves were aseptically collected via jugular vein puncture. Blood for biochemical analysis was collected into silicone coated plastic tubes with no anticoagulant (BD Vacutainer ${ }^{\circledR}$ Venous Blood Collection, BD Diagnostics, NJ, USA). Blood serum was separated after spontaneous coagulation for $24 \mathrm{~h}$ at $37^{\circ} \mathrm{C}$, and $10 \mathrm{~min}$ centrifugation, at $22^{\circ} \mathrm{C}$, at $1257 \mathrm{xg}$. Samples of $0,5 \mathrm{~mL}$ were immediately used for the quantification of $\mathrm{CIC}$ (see below) and the remaining serum was aliquoted and stored at $-20^{\circ} \mathrm{C}$ until use.

\section{Circulating immune complexes (CIC)}

CIC were isolated by PEG (polyethylene glycol) precipitation assay [11]. The precipitated proteins were redissolved in PBS (phosphate buffered saline), and the optical 
densities at $350 \mathrm{~nm}\left(\mathrm{OD}_{350}\right)$ were measured on Ultrospec 3300pro spectrophotometer (Amersham Bioscience, Uppsala Sweden).

\section{Concentration of serum proteins}

Concentration of serum proteins $(\mathrm{mg} / \mathrm{ml})$ was determined by a commercial bicinchoninic acid assay (BCA assay) (Pierce, Rockford IL, USA) according to the manufacturer's instructions.

\section{Protein agarose gel electrophoresis}

Electrophoresis in 1\% agarose gel buffered with $92 \mathrm{mM}$ sodium-barbital buffer, $\mathrm{pH}$ 8.6 was used for analysis of serum proteins $[8,11]$. The relative content of serum protein fractions $(\gamma, \delta$, and $\alpha$ globulins and albumin) was quantified by densitometry using ImageMaster TotalLab TL 120 software (GE HealthCare LifeScience, NJ, USA). Concentration of protein in the protein fractions was calculated based on total protein concentration.

\section{Sodium dodecyl sulfate polyacrylamide gel electrophoresis (SDS-PAGE)}

Non-reducing SDS-PAGE of calves sera (5 $\mu$ g proteins per well, 10 -well comb) in $8 \%$, $0.8 \mathrm{~mm}$ gels was carried out in Perfect Blue ${ }^{\mathrm{TM}}$ Doppler Gel system Twin S (Peqlab Ltd., United Kingdom) [8]. PageRuler'TM Plus molecular size markers size (250, 130, 100, 70, 55, 35, 25, 15 and $10 \mathrm{kDa}$ ) (Thermo Scientific, Rockford, IL, USA) were used. Gels were stained in Coomassie brilliant blue R-250 and distained in an acetic acid/methyl alcohol aqueous solution. Densitometric analysis was performed using the ImageMaster TotalLab TL 120 software.

\section{Zymography assays for detecting activity of matrix metalloproteases (MMP)}

The activity of gelatinolytic MMP (MMP-2 and MMP-9) and caseinolytic matrix MMP (MMP-3 and MMP-13) was assayed as described in Kocić et al. [20]. Sera were ten times diluted in non-reducing sample buffer (125 mM Tris, 4\% SDS, 20\% glycerol, $0.02 \%$ bromphenol blue, $\mathrm{pH}$ 6.8) and in a volume of $20 \mu \mathrm{l}$ subjected to SDS-PAGE under non-reducing conditions in $8 \%$ polyacrylamide gels containing $0.2 \%$ gelatin or $0.1 \%$ casein. Electrophoresis was carried out in SE 260 Mighty Small II Vertical Slab Electrophoresis Unit (GE HealthCare LifeScience, NJ, USA). After being washed twice with 2.5\% Triton X-100, gels were incubated for $24 \mathrm{~h}$ in $100 \mathrm{mM}$ Tris-HCl, pH 8.5 with $10 \mathrm{mM} \mathrm{CaCl}_{2}$. After the gels were stained with Coomassie blue, the MMP activity was detected as transparent band(s) inside the gel. The intensity of bands was quantified by densitometry. 
Activity of urokinase type plasminogen activator (uPA) was assayed by zymography assay also described in Kocić et al. [20]. Ten times diluted sera (volume $20 \mu \mathrm{l}$ ) were subjected to electrophoresis under non-reducing conditions. The acrylamide gels were then placed on top of $1 \%$ agarose gels containing $0.5 \%$ casein and $2 \mu \mathrm{g} / \mathrm{ml}$ plasminogen and incubated at $37^{\circ} \mathrm{C}$ for $24 \mathrm{~h}$. uPA dependent proteolysis of agarose gels was detected as a clear band. The intensity of the bands was quantified by densitometry.

\section{Lipoprotein agarose gel electrophoresis}

SAS-MX Lipoprotein kit (Helena BioSciences Europe, UK) was used. Serum lipoproteins were separated by agarose gel electrophoresis, visualized by Fat Red 7B staining and quantified by densitometry.

\section{One-dimensional thin-layer chromatography (TLC)}

Serum lipids were extracted with chloroform-methanol mixture $(2: 1 \mathrm{v} / \mathrm{v})$, chloroform phase was vacuum evaporated and the lipids were redissolved immediately in chloroform [21]. TLC on silica gel GF plates (Merck, Darmstadt, Germany), was used for the separation and identification of lipids [22]. For neutral lipid separation the solvent system was petroleum ether-diethyl ether-acetic acid $(87: 12: 1 \mathrm{v} / \mathrm{v})$. After the development, lipid spots were visualized using $I_{2}$ vapor staining. The plates were scanned and the lipidograms were analyzed by densitometry. The lipids were identified based on chromatographic mobility of the lipids in standard lipid mixture (C.f.a.s., Calibrator for automated systems; Roche Diagnostics, IN) containing cholesterol ester, triacylglycerol, free fatty acid, diacylglycerol, cholesterol, and various phospholipids.

\section{Concentration of neutral lipids}

Concentrations of triglycerides, total cholesterol and high-density lipoproteins (HDL)cholesterol (mmol/l) were determined on automatic COBAS INTEGRA 400 plus (Roche Diagnostics Limited, Rotkreuz, Switzerland). Concentration of low-density lipoproteins (LDL)-cholesterol was calculated by the Friedewald [23] formula: LDL = TC - HDL - TG/2.2 (mmol/l)

\section{Statistical analysis}

The statistical significance of differences between two groups was determined by the two-tailed T test, using OriginPro 8 software. Differences with p-values of $<0.05$ were considered significant. 


\section{RESULTS}

After clinical examination, 23 calves were classified as having a mild form of bronchopneumonia. Basic hematological indices of peripheral blood of bronchopneumonic calves did not differ from those of healthy calves (Table 1). In the sera of diseased calves, a small but statistically significant increase in concentration of total proteins $(11 \%)$ was found (Table 2). The CIC level (expressed as the PEG precipitates $\mathrm{OD}_{350}$ level) of calves with bronchopneumonia was $0.291 \pm 0.211$ (range $0.144-1.037)$ and it was significantly higher $(\mathrm{p}<0.05)$ than the level of healthy calves $(0.187 \pm 0.065$; range $0.064-0.279)$.

Table 1. Basic haematological indices of peripheral blood of healthy calves and calves with bronchopneumonia.

\begin{tabular}{|c|c|c|}
\hline & $\begin{array}{c}\text { Helathy } \\
(\mathrm{n}=15)\end{array}$ & $\begin{array}{c}\text { Diseased } \\
(\mathrm{n}=23)\end{array}$ \\
\hline $\operatorname{RBC}\left(10^{\circ} / \mathrm{L}\right)$ & $\begin{array}{c}11 \pm 1 \\
(10-12)\end{array}$ & $\begin{array}{c}11 \pm 1 \\
(10-14)\end{array}$ \\
\hline Hct $(\%)$ & $\begin{array}{c}30 \pm 3 \\
(26-35)\end{array}$ & $\begin{array}{c}33 \pm 3 \\
(29-38)\end{array}$ \\
\hline Hemoglobin (g/L) & $\begin{array}{c}92 \pm 9 \\
(83-105)\end{array}$ & $\begin{array}{l}100 \pm 10 \\
(87-117)\end{array}$ \\
\hline WBC $\left(10^{9} / \mathrm{L}\right)$ & $\begin{array}{l}9 \pm 2 \\
(7-12)\end{array}$ & $\begin{array}{l}9 \pm 1 \\
(7-12)\end{array}$ \\
\hline Lymphocytes $\left(10^{9} / \mathrm{L}\right)$ & $\begin{array}{l}5.6 \pm 1.0 \\
(4.1-7.3)\end{array}$ & $\begin{array}{l}6.2 \pm 1.0 \\
(4.8-8.2)\end{array}$ \\
\hline Monocytes $\left(10^{9} / \mathrm{L}\right)$ & $\begin{array}{l}0.31 \pm 0.32 \\
(0.05-0.91)\end{array}$ & $\begin{array}{l}0.20 \pm 0.21 \\
(0.05-0.69)\end{array}$ \\
\hline Granulocytes $\left(10^{9} / \mathrm{L}\right)$ & $\begin{array}{l}2.9 \pm 1.4 \\
(1.5-6.1)\end{array}$ & $\begin{array}{l}2.3 \pm 0.6 \\
(1.3-3.1)\end{array}$ \\
\hline Lymphocytes (\%) & $\begin{array}{l}65 \pm 12 \\
(42-79)\end{array}$ & $\begin{array}{c}71 \pm 7 \\
(62-81)\end{array}$ \\
\hline Monocytes (\%) & $\begin{array}{l}3 \pm 3 \\
(1-9)\end{array}$ & $\begin{array}{l}2 \pm 3 \\
(1-9)\end{array}$ \\
\hline Granulocytes (\%) & $\begin{array}{l}32 \pm 12 \\
(20-59)\end{array}$ & $\begin{array}{c}26 \pm 6 \\
(18-35)\end{array}$ \\
\hline Platelets $\left(10^{9} / \mathrm{L}\right)$ & $\begin{array}{l}485 \pm 122 \\
(218-656)\end{array}$ & $\begin{array}{l}562 \pm 125 \\
(378-745)\end{array}$ \\
\hline
\end{tabular}

The summary data are presented as the mean $\pm \mathrm{SD}$, and minimum through maximum values of given range. 
Table 2. Concentrations of total proteins and protein fractions in the sera of calves with bronchopneumonia

\begin{tabular}{|c|c|c|c|c|c|c|c|}
\hline & & $\begin{array}{c}\text { Healthy } \\
(n=15)\end{array}$ & $\begin{array}{c}\text { Diseased } \\
(n=23)\end{array}$ & & & & \\
\hline \multirow{2}{*}{ Proteins } & \multirow{2}{*}{$\mathrm{g} / 1$} & $63 \pm 10$ & $70 \pm 12 *$ & & & & \\
\hline & & $(48-80)$ & $(60-111)$ & & & & \\
\hline \multicolumn{4}{|c|}{ Agarose gel electrophoresis } & \multicolumn{4}{|c|}{ Non reducing SDS-PAGE } \\
\hline & & $\begin{array}{c}\text { Healthy } \\
(n=15)\end{array}$ & $\begin{array}{c}\text { Diseased } \\
(\mathrm{n}=23)\end{array}$ & & & $\begin{array}{c}\text { Healthy } \\
(n=15)\end{array}$ & $\begin{array}{c}\text { Diseased } \\
(n=23)\end{array}$ \\
\hline \multirow{4}{*}{$\gamma$ globulins } & 0 & $20 \pm 3$ & $22 \pm 6$ & \multirow{4}{*}{ HMW } & \multirow{2}{*}{$\%$} & $5 \pm 4$ & $9 \pm 7$ \\
\hline & 70 & $(16-28)$ & $(12-30)$ & & & $(1-16)$ & $(1-20)$ \\
\hline & \multirow[t]{2}{*}{$\mathrm{g} / 1$} & $13 \pm 4$ & $16 \pm 5^{*}$ & & \multirow{2}{*}{$g / 1$} & $3 \pm 3$ & $6 \pm 4 *$ \\
\hline & & $(8-21)$ & $(7-29)$ & & & $(1-11)$ & $(0.4-15)$ \\
\hline \multirow{4}{*}{$\beta$ globulins } & 0 & $14 \pm 5$ & $13 \pm 5$ & \multirow{4}{*}{$\mathrm{IgG}$} & \multirow{2}{*}{$\%$} & $24 \pm 6$ & $29 \pm 8$ \\
\hline & $\% 0$ & $(8-24)$ & $(3-18)$ & & & $(15-40)$ & $(12-51)$ \\
\hline & \multirow{2}{*}{$\mathrm{g} / 1$} & $9 \pm 4$ & $9 \pm 3$ & & \multirow{2}{*}{$\mathrm{g} / \mathrm{l}$} & $15 \pm 5$ & $21 \pm 9 *$ \\
\hline & & $(4-17)$ & $(2-14)$ & & & $(9-24)$ & $(8-56)$ \\
\hline \multirow{4}{*}{$\alpha$ globulins } & 0 & $7 \pm 3$ & $9 \pm 4 \#$ & \multirow{4}{*}{ Transferrin } & \multirow{2}{*}{$\%$} & $7 \pm 3$ & $11 \pm 5$ \\
\hline & $\% 0$ & $(1-11)$ & $(3-15)$ & & & $(4-13)$ & $(3-17)$ \\
\hline & \multirow{2}{*}{$\mathrm{g} / \mathrm{l}$} & $4 \pm 2$ & $6 \pm 3 *$ & & \multirow{2}{*}{$\mathrm{g} / \mathrm{l}$} & $5 \pm 2$ & $7 \pm 3 *$ \\
\hline & & $(1-7)$ & $(2-11)$ & & & $(2-10)$ & $(2-12)$ \\
\hline \multirow{4}{*}{ Albumin } & 0 & $60 \pm 6$ & $56 \pm 11$ & \multirow{4}{*}{ Albumin } & \multirow{2}{*}{$\%$} & $58 \pm 12$ & $45 \pm 17$ \\
\hline & $\%$ & $(47-67)$ & $(42-77)$ & & & $(38-77)$ & $(24-78)$ \\
\hline & \multirow{2}{*}{$\mathrm{g} / \mathrm{l}$} & $37 \pm 6$ & $40 \pm 11$ & & \multirow{2}{*}{$\mathrm{g} / \mathrm{l}$} & $36 \pm 8$ & $31 \pm 12$ \\
\hline & & $(28-52)$ & $(28-53)$ & & & $(24-46)$ & $(15-55)$ \\
\hline \multirow{2}{*}{$\mathrm{A} / \mathrm{G}$} & & $1.5 \pm 0.3$ & $1.4 \pm 0.7$ & \multirow{2}{*}{$\mathrm{A} / \mathrm{G}$} & & $1.6 \pm 0.7$ & $1.1 \pm 0.9$ \\
\hline & & $(0.9-2.0)$ & $(0.7-3.4)$ & & & $(0.6-2.9)$ & $(0.3-3.6)$ \\
\hline
\end{tabular}

The summary data are presented as the mean $\pm \mathrm{SD}$, and minimum through maximum values of given range; $(*)-p<0.05 ;(\#)-p=0.06 ; \mathrm{A} / \mathrm{G}-$ albumin to globulin ratio; HMW - high molecular weight proteins $(>250 \mathrm{kDa})$.

\section{Protein fractions in the sera of calves with bronchopneumonia: electrophoretic analysis}

Calves' serum proteins were analyzed by agarose gel electrophoresis (Figure 1) and SDS-PAGE under non-reducing conditions (Figure 2). In the agarose gel the proteins of calves' sera were separated into four major fractions: albumin, $\alpha, \beta$ and $\gamma$ globulins. Significant difference in their electrophoretic mobility and relative concentration $(\%)$ was not detected between healthy and diseased calves. However, in the sera of diseased calves the absolute concentration ( $\mathrm{g} / \mathrm{l})$ of $\gamma$ and $\alpha$ globulin increased by $26 \%$ and $56 \%$, respectively (Table 2). SDS-PAGE showed that the concentration of protein 


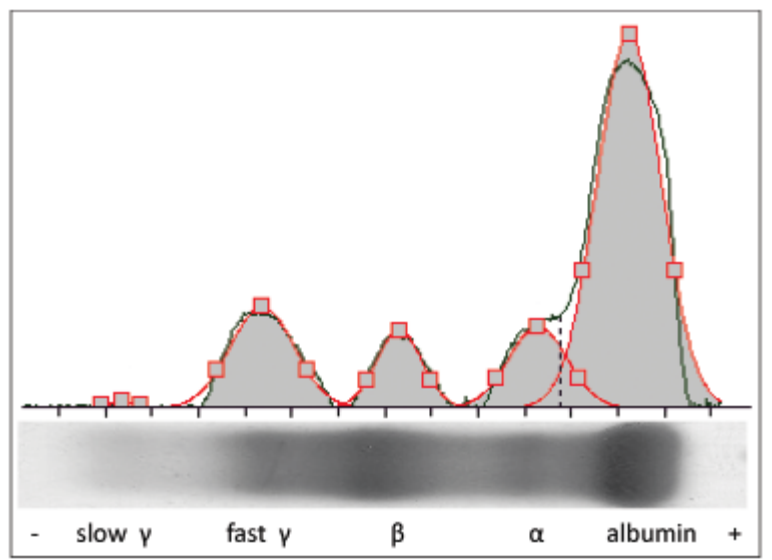

Figure 1. The serum protein agarose gel electrophoretic pattern in calves. $\alpha-\alpha$ globulin, $\beta-\beta$ globulin, $\gamma-\gamma$ globulin. Dark line: Densitometry recorded color intensity; Grey plot/red line: Deconvolution of the densitometric profile.

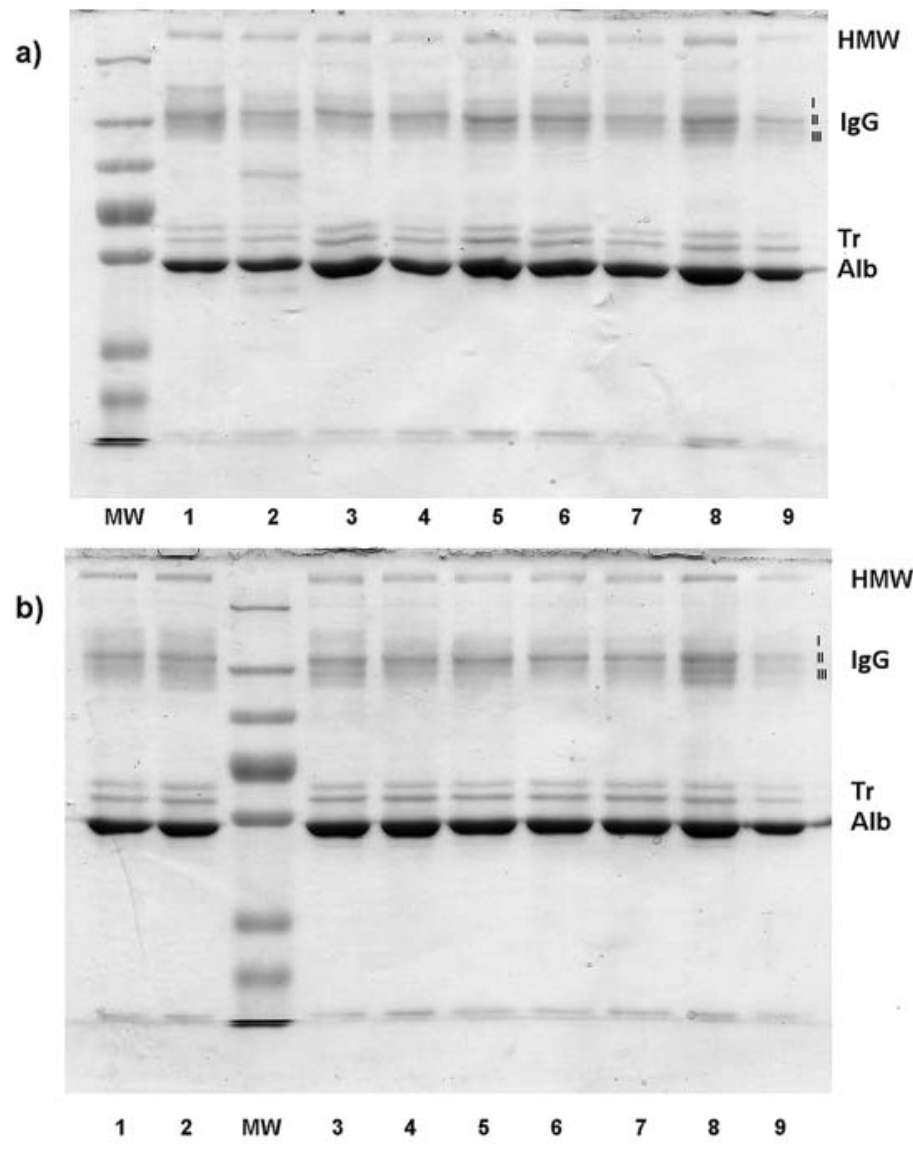

Figure 2. Non reducing SDS-PAGE of serum proteins of a) healthy calves and b) calves with bronchopneumonia. MW - molecular weight markers; Tr - transferrin; Alb - albumin; I,II, and III - IgG fractions. 
fractions of approximately $150 \mathrm{kDa}$, which correspond to different molecular forms of $\mathrm{IgG}$, were significantly higher in the sera of diseased calves than in the control group. Besides, in diseased calves the concentrations of high molecular weight proteins $(>200 \mathrm{kDa})$ and transferrin increased by $79 \%$ and $50 \%$, respectively. A difference in the concentration of albumin between healthy and bronchopneumonic calves was not detected using either agarose-based or SDS-PAGE electrophoretic techniques.

The $\gamma$ globulin fraction (mostly $\operatorname{IgG}$ ) of healthy calves was in agarose gel separated into slow, cationic, $\gamma$ globulin and fast, anionic, $\gamma$ globulin. The relative concentration of these $\gamma$ globulin fractions was unchanged in the sera of diseased animals. However, the absolute concentration $(\mathrm{g} / \mathrm{l})$ of fast $\gamma$ globulin has increased and led to an increase in the concentration of total $\gamma$ globulin (Figure 3a).

The calves' IgG was in non-reducing polyacrylamide gels separated into three fractions with slightly different molecular weight. The increase in concentration of total IgG in the sera of diseased calves detected by SDS-PAGE was the result of an increase in relative and absolute concentration of $\operatorname{IgG}$ subtraction with the lowest molecular weight (Figure 3b).

a)

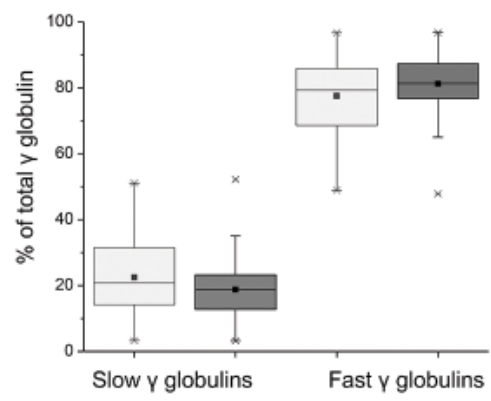

b)

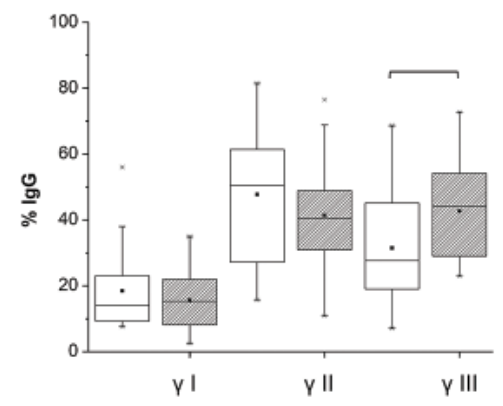

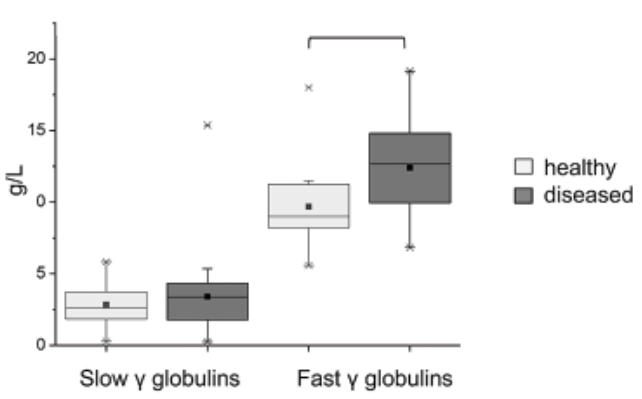

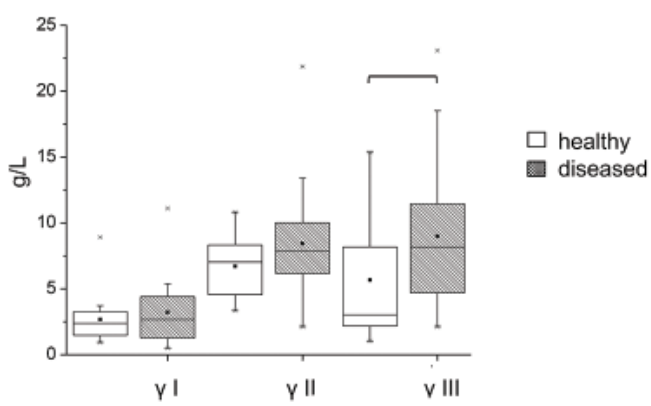

Figure 3. The concentration of serum $\gamma$ globulin ( $\operatorname{Ig} G$ ) fractions in bronchopneumonic calves' sera separated by a) agarose gel electrophoresis and b) non reducing SDS-PAGE. Slow $\gamma$ globulins $=$ cationic $\gamma$ globulins; Fast $\gamma$ globulins $=$ anionic $\gamma$ globulins; $\gamma \mathrm{I}, \gamma \mathrm{II}$, and $\gamma \mathrm{III}$, are IgG fractions arranged in order of descending molecular weight. 


\section{MMP in the sera of calves with bronchopneumonia: Gel zymography}

The activity of gelatinolytic MMP (Figure 4), caseinolytic MMP and uPA in calves' sera was detected by gel zymography assays. In Figure 5 it was shown that sera of both healthy and diseased calves have a gelatinolytic activity expressed as multiple protein bands, among them dominates band of approximately $60 \mathrm{kDa}$ corresponding to MMP2. Increased MMP9 activity was found in the serum of a small number of both healthy and bronchopneumonic animals. Activity of caseinolytic MMP, expressed as two protein bands with similar approximate molecular weight of $50-55 \mathrm{kDa}$, was detected in all sera (not shown). Activity of uPA expressed as one protein band of approximately $55 \mathrm{kDa}$ (not shown) was also registered in all sera analyzed. Relative gelatinolytic and caseinolytic activity, and activity of uPA in the sera of control and bronchopneumonic calves were the same.

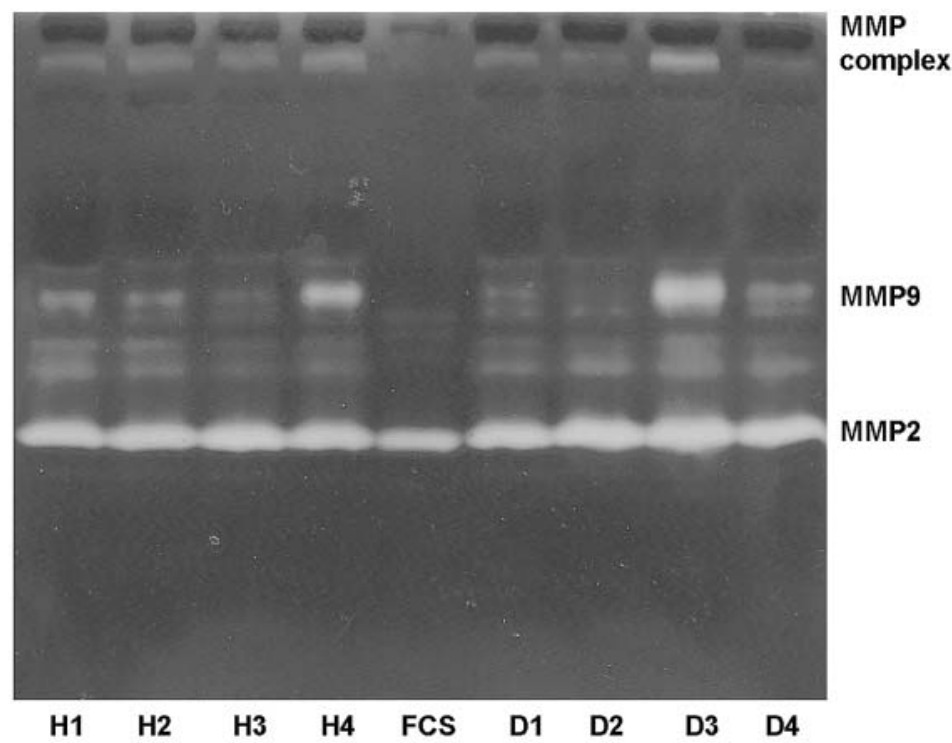

Figure 4. Gelatinolytic activity (MMP2 and MMP9) in sera of calves with bronchopneumonia (D) and healthy calves $(\mathrm{H})$. FCS (fetal calf serum) was used as a gel loading control.

\section{Lipoproteins in sera of calves with bronchopneumonia: electrophoretic analysis}

Agarose gel electrophoresis separated lipoproteins from calves' sera into $\alpha$ (HDL) and $\beta$ (LDL) lipoproteins and chylomicrons, a small fraction which remained in the origin (Figure 5). Very-low-density lipoprotein (VDLD) fraction was found in only one serum of a healthy calf (not shown). The relative concentrations of the Fat Red stained lipoprotein fractions in the sera of diseased calves were equal to those in healthy calves. However, when an absolute concentration of lipid in the separated lipoprotein fraction was assessed based on the intensity of the Fat Red staining, 23\% 
increase in lipid level in fraction of $\alpha$ lipoproteins (HDL) was detected in diseased calves (Table 3).

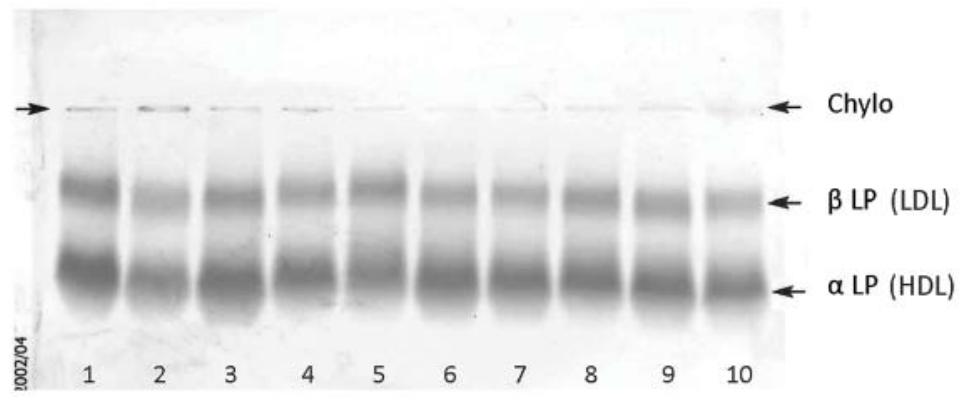

Figure 5. Agarose gel electrophoretic pattern of caves' serum lipoproteins. Line 1-5 - healthy calves; Line 6-10 - calves with bronchopneumonia; Chylo - chylomicrons, LP - lipoproteins.

Table 3. Relative concentrations of lipoprotein fractions in the sera of calves with bronchopneumonia

\begin{tabular}{|c|c|c|c|}
\hline & & $\begin{array}{c}\text { Healthy } \\
(n=15)\end{array}$ & $\begin{array}{c}\text { Diseased } \\
(n=23)\end{array}$ \\
\hline \multirow{3}{*}{ Chylomicrons } & \multirow{2}{*}{$\%$} & $1.8 \pm 2.3$ & $0.9 \pm 0.7$ \\
\hline & & $(0.1-6.7)$ & $(0.0-2.1)$ \\
\hline & colour intensity & $15 \pm 12$ & $12 \pm 10$ \\
\hline \multirow{3}{*}{$\alpha$ lipoproteins } & \multirow{2}{*}{$\%$} & $27.1 \pm 4.7$ & $25.5 \pm 3.8$ \\
\hline & & $(19.2-34.1)$ & $(19.5-32.0)$ \\
\hline & colour intensity & $311 \pm 145$ & $336 \pm 145$ \\
\hline \multirow{3}{*}{$\beta$ lipoproteins } & \multirow{2}{*}{$\%$} & $74.0 \pm 3.1$ & $73.6 \pm 4.1$ \\
\hline & & $(70.1-77.2)$ & $(65.9-81.5)$ \\
\hline & colour intensity & $782 \pm 248$ & $962 \pm 152^{*}$ \\
\hline
\end{tabular}

Relative concentration is expressed as the mean $\pm \mathrm{SD}$, and minimum through maximum values of given range; Colour intensity expressed as the mean $\pm \mathrm{SD}\left(\mathrm{x} 10^{3}\right.$ pixels); $\left(^{*}\right)-\mathrm{p}<0.05$

\section{Lipids in the sera of calves with bronchopneumonia}

With one-dimensional TLC in sera of healthy and bronchopneumonic calves the following lipid classes were detected: cholesteryl esters, triglycerides, free fatty acids, cholesterol and phospholipids (Figure 6). Densitometry analysis of the lipid chromatogram showed that sera of diseased calves contained a smaller proportion of phospholipids and a greater proportion of neutral lipids (cholesteryl esters, triglycerides, free fatty acids and cholesterol) than sera of healthy ones.

Concentrations ( $\mathrm{mmol} / \mathrm{l}$ ) of triglycerides, total cholesterol, HDL cholesterol and LDL cholesterol are given in Table 4. In the sera of diseased calves, no significant change in the concentration of total cholesterol was detected. Additionally, the concentration of HDL cholesterol was increased by $23 \%$ and of LDL cholesterol decreased by $42 \%$. The concentration of triglycerides was also elevated in the sera of diseased calves. 


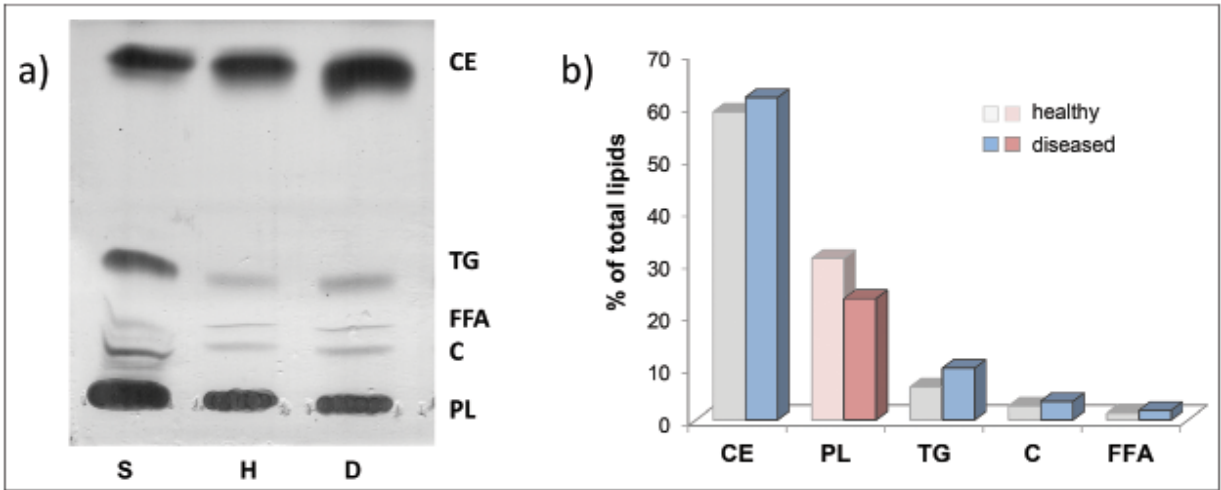

Figure 6. TLC identification of lipids in sera of calves with bronchopneumonia. a) Lipid chromatogram; S - Lipid standards, H - healthy and D - diseased (bronchopneumonic) calves. b) The proportion of TLC separated lipid fractions determined by densitometry. CE Cholesteryl esters, TG - triglyceride, FFA - free fat acids, C - cholesterol, PL - phospholipids. $\mathrm{S}$ - Lipid standards, $\mathrm{H}$ - healthy and D - diseased (bronchopneumonic) calves.

Table 4. The concentration of neutral lipids in the sera of calves with bronchopneumonia

\begin{tabular}{lcc}
\hline mmol/L & $\begin{array}{c}\text { Healthy } \\
(\mathbf{n}=\mathbf{1 5})\end{array}$ & $\begin{array}{c}\text { Diseased } \\
(\mathbf{n}=\mathbf{2 3})\end{array}$ \\
\hline Total cholesterol & $2.43 \pm 0.06$ & $2.66 \pm 0.44$ \\
& $(1.22-3.35)$ & $(1.85-3.43)$ \\
HDL cholesterol & $1.77 \pm 0.57$ & $2.18 \pm 0.36 *$ \\
& $(0,63-2,67)$ & $(1,51-2,77)$ \\
LDL cholesterol & $0.53 \pm 0.42$ & $0.31 \pm 0.11 \#$ \\
& $(0.10-1.59)$ & $(0.11-0.52)$ \\
Triglycerides & $0.29 \pm 0.06$ & $0.36 \pm 0.09 *$ \\
& $(0.21-0.39)$ & $(0.19-0.55)$ \\
\hline
\end{tabular}

The results are presented as the mean $\pm \mathrm{SD}$ and minimum through maximum values of given range; $(*)-\mathrm{p}<0.05 ;(\#)-\mathrm{p}=0.07$.

\section{DISCUSSION}

It is known that for the diagnosis and monitoring of the efficacy and safety of therapy of human lung inflammatory diseases for the analysis of the expression of stable biomarkers in the serum, bronchoalveolar lavage fluid and sputum is necessary [24]. Although the same is true for calf bronchopneumonia, reliable biomarkers for their accurate diagnosis are not defined yet.

The polymicrobial nature of calf bronchopneumonia points to the need for microbiological testing to ensure adequate antibiotic therapy. Cultures of bronchoalveolar lavage fluids are considered to be the most reliable for the identification 
of causative microbial agents but DeRosa et al. [25] showed that calve's nasal swab cultures are representative of isolates present in the lungs and Taylor et al. [26] showed that nasal sampling, when combined with clinical diagnosis, may provide greater diagnostic accuracy and improve treatments. In this study, as well as in our previous studies [8,11] conducted during 2012-2016 period on the same farm, a gram negative bacterium, P. multocida, was abundantly found in nasal swabs of all diseased calves while other pathogenic bacteria or fungi were not isolated. These results indicate the most important role of this bacterium for the development of bronchopneumonia in the analyzed farm. Viral-bacterial synergistic interaction is important in the pathogenesis of calf bronchopneumonia [1,9], it was neither possible to determine the causative viral agents nor to estimate the magnitude of their impact on the results obtained.

An elevated level of CIC was detected in many infectious/inflammatory diseases in humans [27]. It is believed that CIC are formed at the site of inflammation and represent an overflow from the inflamed/injured tissue. With feasible PEG precipitation assay we confirmed the presence of CIC in the circulation of healthy calves six hours after birth, and showed that their synthesis is part of a normal physiological immune response throughout lifetime. In this study, as well as in our previous studies $[8,11,28]$, we showed that calf bronchopneumonia was accompanied by increased levels of CIC and we showed that their IgG are structurally and functionally different from those of healthy calves. The fact that CIC are elevated in all analyzed bronchopneumonic calves $[8,11,28]$ and their additional increase in animals without therapy, seven days after detection of the disease [28] indicate that CIC could be an accurate biomarker of calf bronchopneumonia.

Peripheral blood leukocyte count is considered to be the easiest method to identify infections in humans and animals. In this work we haven't detected an increase in total leukocyte or neutrophil counts, even though their increased level in calf bronchopneumonia was reported [8,11,13,15,18]. Back in 1982 Yates [29] pointed out that in different cases of calf bronchopneumonia the leukocyte counts could vary from leucocytosis to leukopenia. We believe that these variations are a result of 1) multifactorial aetiology of the disease, 2) potent immunomodulatory effects of microbiological causative agents [1] and 3) time-dependent fluctuation in the number of leukocytes in peripheral blood after disease induction [30]. All of these factors must be taken into consideration before declaring increased peripheral blood leukocyte count as a suitable biomarker of calf bronchopneumonia.

Similar to the leukocyte count, in calves with bronchopneumonia, the concentration of peripheral blood erythrocytes could be unchanged [16,18], decreased [13] or increased [11]. Anemia in calves with bronchopneumonia could be a consequence of iron deficiency or infection per se, and can lead to the weakening of the immune response and increased risk of infections [31]. Šoltésová et al. [18] assumed that the increased concentration of hemoglobin could be an adaptation mechanism to hypoxemia in calves with chronic respiratory diseases. However, we are of the opinion that the detected increase in peripheral blood erythrocytes count, haematocrit and 
concentration of hemoglobin could also reflect a mild dehydration (especially if it is accompanied with a significant increase in the concentration of total proteins) as it was noted in our previous study [11]. We considered the increased body temperature in diseased calves to be the cause of dehydration. Also, diarrhea precedes pneumonia in up to 60\% of calves [2] and might be one of the reasons for dehydration. Because of that we wanted to emphasize that changes in blood volume should be calculated (as described in Costill and Fink) [32] when the influence of lung disease on concentration of peripheral blood cells, proteins and molecular constituents is analyzed.

Agarose gel electrophoresis and SDS-PAGE are widely applied diagnostic methods in human medicine [33]. In veterinary medicine these techniques are almost exclusively used for research purposes. We have showed along with other authors [16,34] that agarose gel electrophoresis separates serum proteins of both bronchopneumonic and healthy calves into four major fractions: albumin and $\alpha, \beta$ and $\gamma$ globulins. In all these studies an increase in the concentration of $\alpha$ globulin was detected. However, data on concentrations of other electrophoretic fractions of bronchopneumonic calves' serum proteins varied. Albumin is a negative acute phase protein and, in accordance with this property, several research groups reported its reduced concentration in sera of bronchopneumonic calves [13,15,34]. However, in the present study as well as in our previous study [16] a decrease in the concentration of serum albumin in diseased calves was not detected. Don and Kaysen [36] have stated that in inflammatory diseases in humans, hypoalbuminemia could be a result of the combined effects of inflammation per se (i.e. of the greater catabolic rate and increased transfer of albumin out of the vascular compartment) and inadequate protein synthesis (inflammation induces anorexia and malnutrition, which decreases rate of albumin synthesis). In the bronchopneumonic calves analyzed by our research group these factors couldn't be regarded strong enough to provoke hypoalbuminemia.

Humbelt et al. [34] reported that $\beta$ globulin was increased in the sera during the course of recovery after bronchopneumonia. This result was in accordance with the fact that transferrin, a major protein constituent of $\beta$ globulin, is a negative acute phase protein. However, in the present study as well as in our previous study [16], we detected no change in the concentration of $\beta$ globulin in bronchopneumonic calves. Our result differed from the results of who reported that calves with respiratory diseases had increased levels of $\beta$ globulin. With non-reducing SDS-PAGE we have detected an increased level of proteins, which according to their molecular weight $(\sim 80 \mathrm{kDa})$ corresponds to transferrin. Although the increased transferrin level reflects iron deficiency [37] we assume that in this case it may represent an adaptive mechanism. Ellison et al. [38] showed that transferrin, by damaging the outer membrane of gram-negative bacteria and altering the outer membrane permeability, realizes its antimicrobial activity against gram-negative bacteria. If this protective activity of transferrin exists in calves with mild pneumonia remains to be unraveled.

The results of our research group that are found to be in accordance with other research groups $[15,34]$ have shown that calf bronchopneumonia is accompanied 
with an increased concentration of $\gamma$ globulin fraction, which predominantly contains IgG antibodies. In an electric field bovine $\gamma$ globulins are separated into cationic and anionic fractions. IgG2 are predominately found in the fraction of slow, cationic $\gamma$ globulins, while $\operatorname{IgG}$ are moving towards the anode as a fraction of fast, anionic $\gamma$ globulins [39]. Peak onset of bronchopneumonia in calves is at two to four months of age. In this period, the concentration of total serum $\operatorname{IgG}$ and $\operatorname{IgA}$ [39] and the concentration of $\mathrm{IgG}$ antibodies specific for $M$. haemolytica, and P. multocida are at their lowest level [40]. In the present study we detected an increase in the concentration of total serum $\gamma$ globulins in bronchopneumonic calves, and it was the result of an increase in the concentration of anionic $\gamma$ globulins, which predominately contain IgG1. IgG1 synthesis is part of the non-inflammatory Th2 response characteristic for immature calves [41], but at the same time this antibody is described as nonprotective against some of bronchopneumonia causative agents [10,42,43]. It is believed that the imprecise regulation of complex interactions of pro-inflammatory components of host immune response, necessary for pathogen removal, and antiinflammatory components responsible for repair of injured lung tissue are critical for the pathogenesis of this disease [1] and we think that the disturbed Th1/Th2 balance could be (roughly) assessed based on concentrations of $\gamma$ globulin fractions. In SDSPAGE we detected three protein fractions slightly different in their electrophoretic mobility, which molecular weight corresponded to IgG. Increased concentration of total serum IgG in bronchopneumonic calves resulted from an increased concentration of the fraction with the lowest molecular weight. Bovine IgG exist in several isotypic and allotypic variants [44] and can be differentially glycosylated [8] and more detailed analysis should be performed to precisely identify, which molecular variants of $\operatorname{IgG}$ are increased in bronchopneumonic calves. $\operatorname{IgA}$ in bovine serum exists exclusively in the dimeric form [45] and we think that the increase in the level of high molecular weight proteins in sera of bronchopneumonic calves might reflect increased synthesis of $\operatorname{IgA}$ and $\operatorname{IgM}$ and/or some of high molecular weight acute phase proteins [30,46]. Precise identification of constituents of the fraction of high molecular proteins requires further analysis.

MMPs are endopeptidases which degrade proteins of extracellular matrix (ECM) (collagens, elastin, gelatine, matrix glycoproteins, and proteoglycan) but also many other non ECM proteins. Their secretion is detected in inflamed lung tissue and bronchoalveolar lavage fluids in humans and animals and they are implicated in a variety of pulmonary pathologies, playing important roles in both lung tissue injury and repair [47]. Gel zymography is a widely accepted method for the detection of the presence and activity of MMPs and by using this method it was shown that MMP9 concentration and activity is increased in the plasma of people suffering from community-acquired pneumonia [48]. Calf bronchopneumonia is characterized by massive cellular influx and lung tissue remodeling and matrix metalloproteases have been studied as key factors in tissue remodeling. Thus, increased concentration and activity of gelatinases (MMP2 and MM9) were detected in lung lesion of calves with 
experimentally induced $M$. haemolytica pneumonia [4] and in tracheobronchial lavage fluid of calves with concurrent infections of P. multocida and M. bovirhinis [49]. Hinds et al. [30] using intravenous application of E. coli lipopolysaccharide as a model for acute phase protein responses showed that covalent MMP-9 haptoglobin complex (Hp-MMP-9) was detected in the serum before and declined more rapidly than other acute phase proteins, and assumed that Hp-MMP9 complex can be early and accurate markers of calf respiratory diseases. The serum level of Hp-MMP9 complex was confirmed as a reliable biomarker of acute lung inflammation in calves experimentally infected with $M$. haemolytica [46]. Although the role of MMPs in calf bronchopneumonia has been proved we did not find an increase in relative concentration and activity of gelatinolytic and caseinolytic MMPs and urokinase in the sera of diseased calves. These results might indicate that in calves with mild bronchopneumonia increased expression/activity of MMPs could be detected locally at the site of inflammation, but not in systemic circulation and that concentration and activity of MMPs in their sera cannot be accurate biomarkers of the disease.

It is well known that lipids and lipoproteins act as potent immunomodulators and that their serum concentration is changed in natural or experimentally induced infectious/ inflammatory diseases [50,51]. In humans, reduction of concentrations of HDLcholesterol and phospholipids and an increase in the concentration of triglycerides and VLDL-cholesterol are described as the most frequent changes in serum or plasma lipid contents. Nevertheless, this scheme is not uniform, and it largely depends on the infectious agents and disease severity [52,53]. Our results showed that serum concentration of phospholipids was decreased and the concentration of triglycerides was increased in bronchopneumonic calves, which was in accordance with the data obtained in calf bronchopneumonia $[13,15,54]$ and in many human inflammatory diseases [53,54]. However, unlike other authors [13,15,54] we found that in calves with bronchopneumonia the concentration of total cholesterol was unchanged and the concentration of HDL-cholesterol was even elevated. HDL binds and neutralizes bacterial lipopolysaccharides and attenuates inflammatory response [50,51] and we assume that this increase in HDL concentration (and probably changes in their protein and lipid constituents) can be an adaptive mechanism developed in response to bacterial infection and can lead to the resolution of inflammation. To confirm this hypothesis besides the concentration of HDL lipoproteins it would be necessary to analyze their molecular constituents in detail.

Although our results are consistent with the results of many other authors who showed that analysis of serum proteins and lipids can be useful diagnostic tool in calf bronchopneumonia, the overall results are not always consistent. Most of the studies are conducted on a small number of calves and without identification of causative agents. We consider that future research targeted at establishing reliable biomarkers in calf bronchopneumonia should be 1) conducted on a significantly higher number of calves, 2) directed at identifying microbiological and environmental causative agents and 3) the same analytical methods should be used by different research groups. 
This points to the necessity of organizing (conducting) multi-center research with participation of large-scale commercial farms located in regions that share similar climates, ecological and geographic characteristics.

\section{Acknowledgement}

This work was supported by OI175062, III46002 and OI175053 grants from the Ministry of Education, Science and Technological Development of Republic of Serbia

\section{Authors' contributions}

IV and FN designed and oversaw the research, analyzed data, and wrote the manuscript. MK, DM, IM, SO, JG-M, AA, ZM, OS designed and performed experiments, analyzed data, and assisted with preparation of the manuscript.

\section{Declaration of conflicting interests}

The author(s) declared no potential conflicts of interest with respect to the research, authorship, and/or publication of this article.

\section{REFERENCES}

1. Mosier D; Review of BRD pathogenesis: the old and the new: Animal Health Research Reviews 2014, 15:166-168.

2. Corbeil LB, Watt B, Corbeil RR, Betzen TG, Brownson RK, Morrill JL: Immunoglobulin concentrations in serum and nasal secretions of calves at the onset of pneumonia. Am J Vet Res1984, 45:773-778.

3. Härtel H, Nikunen S, Neuvonen E, Tanskanen R, Kivelä SL, Aho R, Soveri T, Saloniemi $\mathrm{H}$ : Viral and bacterial pathogens in bovine respiratory disease in Finland. Acta Vet Scand 2004, 45:193-200.

4. Starr AE, Dan T, Minhas K, Shewen PE, Coomber BL: Potential involvement of gelatinases and their inhibitors in Mannheimia baemolytica pneumonia in cattle. Infect Immun 2004, 72:4393-4400.

5. Autio T, Pohjanvirta T, Holopainen R, Rikula U, Pentikäinen J, Huovilainen A, Rusanen H, Soveri T, Sihvonen L, Pelkonen S: Etiology of respiratory disease in non-vaccinated, nonmedicated calves in rearing herds. Vet Microbiol 2007, 119:256-665.

6. Nikunen S, Härtel H, Orro T, Neuvonen E, Tanskanen R, Kivelä SL, Sankari S, Aho P, Pyörälä S, Saloniemi H, Soveri T: Association of bovine respiratory disease with clinical status and acute phase proteins in calves. Comp Immunol Microbiol Infect Dis 2007, 30:143-151.

7. Orro T, Pohjanvirta T, Rikula U, Huovilainen A, Alasuutari S, Sihvonen L, Pelkonen S, Soveri T: Acute phase protein changes in calves during an outbreak of respiratory disease caused by bovine respiratory syncytial virus. Comp Immunol Microbiol Infect Dis 2011, 34:23-29. 
8. Fratrić N, Gvozdić D, Vuković D, Savić O, Buač M, Ilić V: Evidence that calf bronchopneumonia may be accompanied by increased sialylation of circulating immune complexes`IgG. Vet Immunol Immunopathol 2012, 150:161-168.

9. Agnes JT, Zekarias B, Shao M, Anderson ML, Gershwin LJ, Corbeil LB: Bovine respiratory syncytial virus and Histophilus somni interaction at the alveolar barrier. Infect Immun 2013, 81:2592-2597.

10. Mulongo M, Prysliak T, Perez-Casal J: Vaccination of feedlot cattle with extracts and membrane fractions from two Mycoplasma bovis isolates results in strong humoral immune responses but does not protect against an experimental challenge. Vaccine 2013, 31:14061412.

11. Buač M, Mojsilović S, Mišić D, Vuković D, Savić O, Valčić O, Marković D, Gvozdić D, Ilić V, Fratrić N: Circulating immune complexes of calves with bronchopneumonia modulate the function of peripheral blood leukocytes: In vitro evaluation. Res Vet Sci 2016, 106:135142.

12. Al-Quadah KM: Oxidative stress in calves with acute or chronic bronchopneumonia. Revue Méd Vét 2009,160:231-236.

13. Almujalli AM, El-Deeb WM, Eljalii EM, Fouda TA, AlBlwy M: Clinical, biochemical and bacteriological investigation of pneumonia in calves with special reference to alpha-1-acid glycoprotein response. Int J Vet Health Sci Res 2015, 3:60-63.

14. Abdallah A, Hewson J, Francoz D, Selim H, Buczinski S: Systematic Review of the Diagnostic Accuracy of Haptoglobin, Serum Amyloid A, and Fibrinogen versus Clinical Reference Standards for the Diagnosis of Bovine Respiratory Disease. Journal Vet Intern Med 2016, 30:1356-1368.

15. Civelek T, Kav K, Camkerten I, Celik HA, Acar A: Effects of bacterial pneumonia in neonatal calves on serum lipids. Bull Vet Inst Pulawy 2007, 51:503-507.

16. Fratrić N, Ilić V, Gvozdić D, Vuković D, Savić O, Jagličić I: A hematological profile and plasma proteins of three months old calves with clinical signs of bronchopneumonia. Veterinarska stanica 2011, 42 (Supplemet 1):72-77.

17. Nagy O, Tóthová C, Seidel H, Paulíková I, Kovác G: The effect of respiratory diseases on serum lactate dehydrogenase and its isoenzyme patterns in calves. Pol J Vet Sci 2013, 16:211-218.

18. Šoltésová H, Nagyová V, Tóthová C, Nagy O: Haematological and blood biochemical alterations associated with respiratory disease in calves. Acta Veterinaria Brno 2015, 84:249256.

19. McGuirk, SM: Otitis media in calves. In: Proceedings of 23rd American College of Veterinary Internal Medicine, Baltimore, MD, 2005, pp. 228-230.

20. Kocić J, Santibañez JF, Krstić A, Mojsilović S, Ilić V, Bugarski D: Interleukin-17 modulates myoblast cell migration by inhibiting urokinase type plasminogen activator expression through p38 mitogen-activated protein kinase. Int J Biochem Cell Biol 2013, 45:464-475.

21. Folsh J, Less M, Stanley S: A simple method for the isolation and purification of total lipides from animal tissues. J Biol Chem 1957, 226:497-509.

22. Gloster J, Fletcher RF: Quantitative analysis of serum lipids with thin-layer chromatography. Clin Chim Acta 1966, 13:235-240.

23. Friedewald WT, Levy RI, Fredrickson DS: Estimation of the concentration of low-density lipoprotein cholesterol in plasma, without use of the preparative ultracentrifuge. Clin Chem 1972, 18:499-502. 
24. Röpcke S, Holz O, Lauer G, Müller M, Rittinghausen S, Ernst P, Lahu G, Elmlinger M, Krug N, Hohlfeld JM.: Repeatability of and relationship between potential COPD biomarkers in bronchoalveolar lavage, bronchial biopsies, serum, and induced sputum. PLoS ONE 2012, 7:e46207.

25. DeRosa DC, Mechor GD, Staats JJ, Chengappa MM, Shryock TR: Comparison of Pasteurella $s p p$. simultaneously isolated from nasal and transtracheal swabs from cattle with clinical signs of bovine respiratory disease. J Clin Microbiol 2000, 38:327-332.

26. Taylor JD, Holland BP, Step DL, Payton ME, Confer AW: Nasal isolation of Mannheimia haemolytica and Pasteurella multocida as predictors of respiratory disease in shipped calves. Res Vet Sci 2015, 99:41-45.

27. Hardy KJ, Singh AP, de Shazo RD: Immune Complex Disease. 2009. eLS. [doi: 10.1002/9780470015902.a0002164.pub2]

28. Fratrić N, Ilić V, Gvozdić D, Stojić V, Manojlović M: The levels of PEG precipitatble immune complex in the blood sera from one month old calves with pneumonia. [Article in Serbian, abstract in English: Nivo PEG precipitabilnih imunskih kompleksa u serumima mesec dana starih teladi obolelih od pneumonije] Veterinarski žurnal Republike Srpske. 2010, 10:139-144.

29. Yates WD: A review of infectious bovine rhinotracheitis, shipping fever pneumonia and viral-bacterial synergism in respiratory disease of cattle. Can J Comp Med 1982, 46:225263.

30. Hinds CA, Niehaus AJ, Premanandan C, Rajala-Schultz PJ, Rings DM, Lakritz J: Characterization of the contributions of Hp-MMP 9 to the serum acute phase protein response of lipopolysaccharide challenged calves. BMC Vet Res 2014, 10:261.

31. Graham TW: Trace element deficiencies in cattle. Vet Clin N Am: Food Anim Pract 1991, 7:153-215.

32. Costill DL, Fink W: Plasma volume changes following exercise and thermal dehydration. J Appl Physiol 1974, 37:521-525.

33. Keren DF: Protein electrophoresis in clinical diagnosis. Hodder Arnold, a member of the Hodder Headline Group, London, UK, 2003.

34. Humblet MF, Coghe J, Lekeux P, Godeau JM: Acute phase proteins assessment for an early selection of treatments in growing calves suffering from bronchopneumonia under field conditions. Res Vet Sci 2004, 77:41-47.

35. Safi S: Acute Phase Proteins - Analysis, Clinical Applications and Potentials. In: Mahin Khatam (ed) Inflammatory Diseases - Immunopathology, Clinical and Pharmacological Bases", Chapter 17. INTECH, 2012.

36. Don BR, Kaysen G: Serum albumin: relationship to inflammation and nutrition. Semin Dial 2004, 17:432-437.

37. Weiss DJ, Wardrop KJ (eds): Schalm's veterinary hematology. 6th ed. Wiley-Blackwell, Ames, Iowa, 2010.

38. Ellison RT 3rd, Giehl TJ, LaForce FM: Damage of the outer membrane of enteric gramnegative bacteria by lactoferrin and transferrin. Infect Immun 1988, 56:2774-2781.

39. Kickofen B, Hammer DK, Scheel D: Isolation and characterization of gamma G type immunoglobulins from bovine serum and colostrum. Hoppe-seyler's Z Physiol Chem 1968, 349: 1755-1773. 
40. Prado ME, Prado TM, Payton M, Confer AW: Maternally and naturally acquired antibodies to Mannheimia haemolytica and Pasteurella multocida in beef calves. Vet Immunol Immunopathol 2006, 111:301-307.

41. Chase CC, Hurley DJ, Reber AJ: Neonatal immune development in the calf and its impact on vaccine response. Vet Clin North Am Food Anim Pract 2008, 24:87-104.

42. Corbeil LB. Antibodies as effectors. Vet Immunol Immunopathol 2002, 87:169-175.

43. Hermeyer K, Buchenau I, Thomasmeyer A, Baum B, Spergser J, Rosengarten R, HewickerTrautwein M: Chronic pneumonia in calves after experimental infection with Mycoplasma bovis strain 1067: characterization of lung pathology, persistence of variable surface protein antigens and local immune response. Acta Vet Scand 2012, 54:9.

44. Zhao Y, Jackson SM, Aitken R: The bovine antibody repertoire. Dev Comp Immunol 2006, 30:175-186.

45. Duncan JR, Wilkie BN, Hiestand F, Winter AJ. The serum and secretory immunoglobulins of cattle: characterization and quantitation. J Immunol 1972, 108:965-976.

46. Hanthorn CJ, Dewell GA, Dewell RD, Cooper VL, Wang C, Plummer PJ, Lakritz J: Serum concentrations of haptoglobin and haptoglobin-matrix metalloproteinase 9 (Hp-MMP 9) complexes of bovine calves in a bacterial respiratory challenge model. BMC Vet Res 2014, 10:285.

47. Davey A, McAuley DF, O'Kane CM: Matrix metalloproteinases in acute lung injury: mediators of injury and drivers of repair. Eur Respir J 2011, 38: 959-970.

48. Yang SF, Chu SC, Chiang IC, Kuo WF, Chiou HL, Chou FP, Kuo WH, Hsieh YS: Excessive matrix metalloproteinase-9 in the plasma of community-acquired pneumonia. Clin Chim Acta 2005, 352: 209-215.

49. Simonen-Jokinen TL, Eskelinen UM, Härtel HM, Nikunen SK, Saloniemi HS, Maisi PS: Gelatinolytic matrix metalloproteinases-2 and -9 in tracheobronchial lavage fluid obtained from calveswith concurrent infections of Pasteurella multocida and Mycoplasma bovirbinis. Am J Vet Res 2005, 66:2101-2106.

50. Murch O, Collin M, Hinds CJ, Thiemermann C: Lipoproteins in inflammation and sepsis. I. Basic science. Intensive Care Med 2007, 33:13-24.

51. Pirillo A, Catapano AL, Norata GD: HDL in infectious diseases and sepsis. Handb Exp Pharmacol 2015, 224:483-508.

52. Gallin JI, Kaye D, O’Leary WM: Serum lipids in infection. N Engl J Med 1969, 281:10811086.

53. Alvarez C, Ramos A: Lipids, lipoproteins, and apoproteins in serum during infection. Clin Chem 1986, 32(1 Pt 1):142-145.

54. Joshi V, Gupta VK, Dimri U, Mandal RSK, Sharma DK. Evaluating serum lipid profile in bacterial bovine respiratory disease (BRD) affected calves. Intas Polivet 2015, 16:187-188. 


\section{PROTEINI I LIPIDI SERUMA TELADI SA BLAGOM FORMOM BRONHOPNEUMONIJE: KANDIDATI ZA POUZDANE BIOMARKERE}

KOVAČIĆ Marijana, MARKOVIĆ Dragana, MASLOVARIĆ Irina, OBRENOVIĆ Sonja, GRUJIĆ-MILANOVIĆ Jelica, ARSIĆ Aleksandra, MILANOVIĆ Zorana, SAVIĆ Olivera, FRATRIĆ Natalija, ILIĆ Vesna

Bronhopneumonija teladi je kompleksna multifaktorijalna bolest za čiju su preciznu dijagnozu i odgovarajuću terapiju pored kliničkog pregleda potrebne dodatne mikrobiološke, hematološke i biohemijske analize. Međutim, one se uglavnom ne primenjuju, pre svega zato što biomarkeri bronhopneumonije teladi nisu precizno definisani.

Da bi se utvrdilo koje analize bi bilo svrsishodno raditi u cilju određivanja težine bolesti, analizirali smo 23 teleta stara tri meseca koja su imala blagu kliničku formu bolesti i 15 zdravih teleadi. Pasteurella multocida je izolovana iz nazalnih briseva obolele teladi. Koncentracije eritrocita i leukocita u perifernoj krvi obolele i zdrave teladi nisu bile značajno različite. Proteini, lipoproteini i lipidi seruma teladi su analizirani spektrofotometrijskim metodama, elektroforezom u gelu agaroze, neredukujućom SDS-PAGE, gel zimografijom i tankoslojnom hromatografijom.

U serumima teladi sa bronhopneumonijom je detektovan povišen nivo cirkulišućih imunokompleksa i povećana koncentraciju $\alpha$ globulina, među kojima se nalaze neki od proteina akutne faze. Povećana koncentracija ukupnih $\gamma$ globulina (IgG) je bila rezultat porasta koncentracije anjonskih $\gamma$ globulina (predominantno IgG1). Povećana koncentracija anjonskih $\gamma$ globulina, praćena povećanom koncentracijom transferina (negativnog proteina akutne feze) i HDL-holesterola, smanjenom koncentracijom LDLholesterola i nepromenjenom aktivnosti matriksnih metaloproteza i nepromenjenim brojem leukocita bi mogla da odražava nepostojanje generalizovane inflamacije kod bolesne teladi. Može se zaključiti da je postojala pozitivna korelacija između dobijenih rezultata i blage kliničke slike kod ove teladi. Smatramo da bi analizirani parametri periferne krvi mogli biti primenjeni kao pouzdani markeri bolesti na osnovu kojih bi bilo moguće napraviti razliku između teške i blage forme bronhopneumonije teladi i predvideti povoljniji ishod bolesti kod ove teladi. 